\title{
Analytic Ecclesiology: The Social Ontology of the Church
}

\author{
Joshua Cockayne \\ University of St Andrews
}

\begin{abstract}
In this paper, I aim to show that analytic philosophy can contribute to the theological discussion of ecclesiology. By considering recent analytic work on social ontology, I outline how we might think of the Church as one entity, constituted by many disparate parts. The paper begins with an overview of the theological constraints for the paper, and then proceeds to examine recent work on the philosophy of social ontology and group agency. Drawing on this literature, I outline three models of social ontology from the history of philosophy and suggest reasons why all of them fail to provide an account of the Church's agency. Finally, I develop an alternative model which, I suggest, better fits the conditions stipulated.
\end{abstract}

\section{Introduction}

While analytic theology is still a young and emerging discipline, the lack of work on ecclesiology within this field is striking. Despite pathbreaking work on many of the core doctrines of the Christian faith, work on ecclesiology has sadly not received the same share of attention. ${ }^{1}$ But if, as Oliver Crisp has claimed, analytic theology is

\footnotetext{
1 As William J. Abraham notes, "Theologians are relatively secure on what counts [sic] as relevant topics in ecclesiology; they pursue questions relative to the identity, nature, structures, ministry, sacraments, and mission of the church. It is much less clear what role philosophers should have in this domain" $(2010,170)$. Of these relevant topics, the only notable area of increased interest in the eight years (since Abraham published his discussion) is that of ministry and sacraments. Excellent recent work by Terence Cuneo $(2016)$, Nicholas Wolterstorff $(2015,2018)$ and James Arcadi $(2018)$ has done much to advance the analytic study of ecclesiology by focusing on the sacraments and ministry of the Church. Yet, there is much more to be done. Ecclesiology is a broad field, with many important issues, many of which are of philosophical interest. For instance, whilst there has been an increase of work on the Eucharist, other sacraments have not received the same level of attention. There is surely much that analytic philosophy can contribute to the discussion of the sacraments of baptism, ordination, and marriage. Moreover, while there have been advances in the study of liturgy, much of this discussion makes assumptions about the Church's ontology which could be fleshed out analytically. For instance, in his discussion of the Church's worship, Wolterstorff writes, "The church blesses God, praises God, thanks God, confesses her sins to God, petitions God, listens to God's Word, celebrates the Eucharist. It's not the individual members who do these things simultaneously; it's the assembled body that does these things" $(2015,11)$.
}

Journal of Analytic Theology, Vol. 7, June 2019 10.12978/jat.2019-7.091400021404

(C) 2019 Joshua Cockayne • (C) 2019 Journal of Analytic Theology 
committed to explicating the core claims of the Christian tradition, ${ }^{2}$ and since belief in the "one holy, catholic, and apostolic Church" is a core doctrine of this tradition, ${ }^{3}$ then analytic theologians need to pay more attention to this important area of theology.

This paper seeks to fill this lacuna by addressing an important issue within ecclesiology from the perspective of analytic philosophy. ${ }^{4}$ The primary issue this paper is devoted to is that of the Church's ontology; I seek to give an account of how the Church can be constituted by many individual Christians, and remain united as one, despite its enormous diversity and internal fragmentation. The paper proceeds as follows. First, I outline a minimalist theology of the nature of the Church and its relation to its members, by stipulating the theological constraints of my discussion. Then, drawing from recent work on the philosophy of social ontology and group agency, I consider how thinking philosophically about the Church can help to clarify the minimalist account I describe in the first section. I outline three models of social ontology from the history of philosophy and suggest reasons why all of them fail to provide an account of the Church's agency. Finally, I develop an alternative model which, I suggest, better fits the conditions stipulated.

\section{Stating the question}

First, it is important to note that the use of the term "church" is not always consistent-as William J. Abraham notes, "'church' ... can refer to a building, a local Christian community, a modern Christian denomination, and the whole body of Christians worldwide. Even then, this common usage is deeply contested by various groups of Christians" $(2010,171)$. In this paper, it is the latter use of the term, namely, to refer to the "whole body of Christians worldwide," which I am interested in. More specifically, it is the theological claim that the Christian Church is one united entity which I am concerned with.

The primary question of this paper, then, is this: What kind of thing or entity is the united body of the Church? There are many different answers we might give to this question-As Evelyn Underhill describes it, the Church is a single "organism which is quickened and united by that Spirit of supernatural charity which sanctifies the human race from above" $(1936,83)$. Such unity is not the work of human effort,

\footnotetext{
${ }^{2}$ Crisp defines analytic theology as a form of systematic theology committed to "explicating the conceptual content of the Christian tradition ... using particular religious texts that are part of the Christian tradition, including sacred scripture, as well as human reason, reflection, and praxis (particularly religious practices), as sources for theological judgments" $(2017,160)$ by using the tools of analytic philosophy. Moreover, Crisp suggests, analytic theology as systematic theology should be "done from the perspective of a particular confession for the sake of the church" $(2017,162)$.

${ }^{3}$ Claims about the Church feature in both the Nicene-Constantinopolitan Creed and the Apostles' Creed.

${ }^{4}$ While there is some existing philosophical work which exposits the ecclesiologies of particular thinkers, my approach here will be much more general. See, for instance, Phillip Quinn's (2000) "Kantian Philosophical Ecclesiology," Maria Rosa Antognazza's (2016) work on Leibnizian ecclesiology, and Bruce Kirmsse's (2000) Kierkegaardian ecclesiology.
} 
Underhill notes, but, rather, must be understood in relation "to the purposes and action of God" (1936, 83). In Dietrich Bonhoeffer's work on ecclesiology, he describes the Church as a "collective person" $(1930 / 1998,260)$, constituted by the many individual Christians, capable of both glorifying God and sinning against God.

There are a number of related questions which arise in considering these answers: How can the Church be constituted of such a disparate and divided collection of individuals and remain united? What is the relation between each of these individuals and the wider whole? And how can the Church be capable of acting as a collective person or organism? In many respects, these questions are not unique to the Church; there are many groups who we describe as united in diversity, and capable of acting together, despite being fragmented. We talk of governments, nations, and corporations as united agents, capable of acting, holding beliefs and being held responsible. We also sometimes talk of social wholes as acting together despite disagreement and diversity-indeed, the very task of ruling as a democratically elected government is surely to remain united in spite of division and disagreement. As I will explore in this paper, there is a rich history of philosophical literature devoted to explaining the nature of social wholes. If philosophers can explain the relationship between individuals and the nations which they constitute, then perhaps such explanations can play the same role in our ecclesiology.

Yet, while applications of the philosophical literature on social ontology to questions concerning the Church's ontology can be helpful, such applications also have their limits. As all of the answers above indicate, the Church is a social whole, but one that is unique; in Bonhoeffer's words, the "church is a form of community sui generis" $(1930 / 1998,266)$. Thus, as Paul Avis notes, ecclesiology needs to remain sensitive to both the divine and human aspects of the Church as a unity. He writes that, although the Church

comes from God and depends on God, it is fully embedded in creaturely reality, in all the changes and chances, the risks and dilemmas of this world. It is bound up in the historical, the political, and the social complexion of human life in the world...the church is also contaminated by human sin and crime. But in spite of all that, the divine origin and divine upholding of the church do shine through $(2018,9)$.

This paper seeks to draw insights from the philosophical literature on social ontology, while remaining sensitive to the theological constraints of Christian Scripture and tradition. ${ }^{5}$ We begin, then, by considering the theological parameters of analytic ecclesiology. ${ }^{6}$

5 Note that one related philosophical question is that of composition and identity-if the Church is
constituted by its members, is it identical to its members? Or is it somehow more than the sum of its
parts? One's answer to this question will depend on one's stance on mereology, and whether one takes
constitution and identity to be the same relation. See Baxter and Cotnoir (eds., 2014) for a recent
collection in defence of the composition as identity view. This is not a point I will explore here.
${ }^{6}$ It is important to clarify at this point that to give a philosophical explanation is not to diminish the
mystery of the doctrine of the Church. There is a helpful analogue in theological methodology which
can be of use here. Avery Dulles describes his theological task as working with "models," "aspects," or 


\section{Setting the constraints}

There are, no doubt, hundreds of possible philosophical accounts of the nature of the Church which might be given, however, here I seek to give an account which is within the general constrains of theological orthodoxy. Thus, I outline some minimal theological claims which will act as constraints for the proceeding discussion. ${ }^{7}$ I provide some brief commentary on each of these points below:

1. The Church is constituted by individual Christian disciples. ${ }^{8}$

2. These individual Christian disciples at times coalesce into gathered collectives.

3. The gathered collectives and individuals which partly constitute the Church are not united in practice, theology or belief.

4. Such disunity arises, at least partly, because of the sin of those who constitute the Church.

5. The Holy Spirit unites the actions of the constituent parts of the Church to respond to God in worship, through Christ.

6. Christ has authority and headship over the Church.

Let us take each claim in turn.

\section{The Church is constituted by individual Christian disciples.}

In Scripture, there are at least 96 metaphors used to explain the nature of the Church (Minear 1960, 25). The most well-known of these metaphors, perhaps, is the Apostle Paul's description of the Church as Christ's body, in which members each play different roles, united together to act as one (1 Corinthians 12:12-31). ${ }^{9}$ Elsewhere, we are told that the individual members are like bricks, which together constitute a

\footnotetext{
"dimensions" and never describing the Church "directly," since the Church is ultimately mysterious $(1978,14)$. Dulles suggests that indirect descriptions of the Church can allow us to grow in understanding of the Church, as long as these descriptions remain indirect. I suggest that by providing a philosophical explanation of one possible way in which the Church may be united yet divided, the same might be said. The explanations which I explore in the remainder of this paper are models, intended to expand our understanding of the Church, but without giving an ultimate account of the Church. Ultimately, as I will conclude, whilst such thinking can be helpful, it must remain modest in its aims. In what follows, I consider how the philosophy of social ontology might provide one philosophical explanation to understand the Church's one-ness in spite of its division.

${ }^{7}$ While, in an ideal world, it might be preferable to provide a detailed theological justification for a particular ecclesiology, and then to consider the application of philosophy to it, such a task would very quickly spiral out of control. Thus, instead of giving a thorough defence of a particular theological stance, I offer a number of assumptions which act as constraints for the proceeding discussion. The intention is that these assumptions are relatively uncontroversial, theologically speaking, and broadly consistent with the New Testament discussions of ecclesiology.

8 Thanks to an anonymous referee for help in summarizing these points as clearly and broadly as possible.

${ }^{9}$ This is not the only place in which we find such an analogy. For example, the metaphor of the body and its parts is used in a number of places, for example, Colossians 1:18-20, Colossians 3:12-17, Romans 12:3-8.
} 
temple (2 Corinthians 6:14-18, 1 Corinthians 6:18-20, 1 Corinthians 3:10-17), or a household constituted by many stones (1 Timothy 3:14-15, Ephesians 2:11-20, 1 Peter 2:3-8). The metaphors of the New Testament share a common feature: the Church is described throughout Scripture as being a unity, in which many different individuals are brought together as one..$^{10}$ Note that while the above claim states that the Church is constituted by individual Christian disciples, it does not state that it is wholly constituted by these individuals. The Church might also include the hosts of heaven - the angels and archangels, as well as the Saints gathered in glory. This will depend, in part, on one's own theological stance, and I remain neutral on these possibilities.

\section{These individual Christian disciples at times coalesce into gathered collectives.}

An important feature of the relationship between the Church and gathered church collectives is that gathered churches seek to be related to the Church in some way. These gathered communities of individual churches, act as the "here-and-now embodiment" (Underhill, 1936, 86) of the Church as a united whole. We might also make a normative claim concerning the relationship between gathered church collectives and the Church-in Hans Küng's words, "The Church is one, and therefore should be one" (1967, 273-274; emphasis in the original). The important point for our purposes is that a gathered church collective ought to (or at least ought to strive to) resemble the unity of the Church as a whole entity. ${ }^{11}$

\section{The gathered collectives and individuals which partly constitute the Church are not united in practice, theology or belief.}

As the Christian Church rapidly expanded, the claims made by Scripture about the unity of the Church were reiterated-the Nicene-Constantinopolitan Creed (381 AD) states, "We believe ... in one holy catholic and apostolic Church." Yet, the Church, as it exists today, is splintered and theologically divided in a way which must have been unimaginable to the original readers of the New Testament. Support for this claim can be seen by attending to the empirical facts about all of the groups which identify as belonging to the Church today. If this Church is a united entity, it is united in spite of enormous schism and diversity. As Avis describes it,

Ecclesiology wrestles with the truth that the church is at one and at the same time both united and divided. It knows itself to be united in Christ;

\footnotetext{
${ }^{10}$ Moreover, as N.T. Wright notes, "from our earliest evidence, the Christians regarded themselves as a new family, directly descended from the family of Israel, but now transformed" $(1997,447)$. The Second Vatican Council stresses a similar point, noting that "The Church of Christ acknowledges that in God's plan of salvation the beginning of faith and election is to be found in the patriarchs, Moses, and the prophets" (Flannery (ed.), 1975, 391). While the relationship between Israel and the Church has many layers of theological complexity, the point for our purposes here seems clear: The Church is a united body, composed of many distinct parts.

11 The agency of the gathered church is something I consider in more detail in Cockayne (2018).
} 
its unity is part of its confession; but it also knows itself to be lamentably divided.... [T] he fact of the fragmentation of the one church is the almost unbearable paradox that confronts ecclesiology $(2018,24)$.

It is clearly possible that not all of these self-identified members of the Church actually belong to the Church, and there are some ecclesial traditions which will simply deny that there is any substantial schism in the true Church. ${ }^{12}$ The unbearable paradox of ecclesiology which Avis describes here will not arise if one thinks that the Church is undivided. In this case, one's ontology of the Church will be relatively straightforward. Yet, any ecclesiology which recognises these diverse groups as belonging to the Church in some way, must wrestle with the issue of how to reconcile such division with an account of unity.

\section{Such disunity arises, at least partly, because of the sin of those who constitute the Church.}

Diversity appears to be at the heart of many of the Biblical passages concerning the unity of the one Church. For instance, writing on the body metaphor in 1 Corinthians 12, Gordon Fee writes that, "Paul's primary concern with this imagery is not that the body is one even though it has many members, thus arguing for their need for unity despite their diversity. Rather, his concern is expressed in v. 14, that even though the body is one, it does not consist in one member but of many, thus arguing for their need for diversity, since they are in fact one body" (Fee, 601; emphasis in the original). ${ }^{13}$

While diversity is clearly affirmed in the New Testament as important for the Church, the diversity Paul has in mind in 1 Corinthians appears to be a diversity of gifts and diversity of belonging. The diversity we see in the contemporary Church appears to be a source of disunity. As Fee puts this point, "what is disconcerting" about the contemporary Church,

\footnotetext{
${ }^{12}$ Vatican II suggests that whilst the Catholic Church is the true Church, there are "elements of sanctification and of truth... found outside of its visible structure" (1964, Chapter 1.8). It also describes those outside of the Catholic Church as "separated" (1964, Chapter 8.4), suggesting that, to some extent, these factions still belong to the Church of Christ, even if they lie outside of its visible structures. Although this claim is perhaps weaker than the one outlined in 3, it still requires us to say something about how unity in diversity is possible. Thus, as McGrath describes it, the Second Vatican Council moves away from an "imperialist approach, which declares that there is only one empirical ... church which deserves to be known as the true church ... [in] recognizing other Christian churches as 'separated' Christian brothers and sisters" $(2011,392)$.

${ }^{13}$ As C.K. Barrett notes,
}

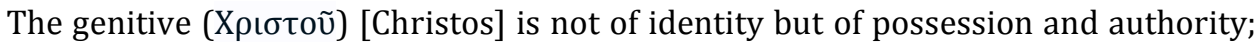
not, the body which is Christ, of which Christ consists, but, the body that belongs to Christ, and over which he rules ... separate from the body even though continuous with it. Since the resurrection... Christ has been the new humanity living in the new age. His members have their place in this eschatological entity, and, as members of it, must live accordingly $(1971,292)$. 
is that what for Paul is the basis of unity, namely, their common life in the Spirit, has in later times become the point of so much tension.... [I]f the work of the Spirit appears to be the cause of disunity among some, it is certainly not the Spirit's fault. Our common fallenness unfortunately often causes both pride and suspicion or distrust to prevail when it comes to the work of the Spirit $(1987,607) .{ }^{14}$

In part, then, the disunity in the Church is a result of human disobedience or defiance. A stronger claim is often made, namely, that the Church is not only divided because of the sin of individual members, but also, that the Church itself is sinful in some respect. As the Catholic Catechism puts it, the Church is "at once holy and always in need of purification" (Flannery (ed.), 1975, 358)..$^{15}$ Or as Dietrich Bonhoeffer puts this point, "Among human beings there is no such thing as a pure, organic community life. The peccatorum communio [community of sin] continues to coexist within the sanctorum communio." (1930/1998, 213). Any account which seeks to explain the nature of the Church, then, must say something about its sinful nature. ${ }^{16}$

\section{The Holy Spirit unites the actions of the constituent parts of the Church to respond to God in worship, through Christ.}

Because of the common work of the Spirit at work in each member of the Church, Paul regards the Church as having a unity brought about by the Spirit. As Fee describes, in the discussion of unity in 1 Corinthians 12, Paul's primary concern "is not to delineate how an individual believer becomes a believer, but to explain how they, though many, are one body. The answer: The Spirit, whom all alike have received" $(1987,603)$. This emphasis is also reflected in the creedal claims about the Church: in the NiceneConstantinopolitan Creed the claims concerning the "holy, catholic, apostolic Church" follow from the claim, "we believe in the Holy Spirit."17 As Karl Barth puts this point, to state "I believe in the church," means

that I believe that here, at this place, in this assembly, the work of the Holy Spirit takes place. By that is not intended a deification of the creature; the church is not the object of faith, we do not believe in the church; but we do believe that in this congregation the work of the Holy Spirit becomes an event $(1959,143)$.

\footnotetext{
${ }^{14}$ In Bonhoeffer's words, "The community of saints as the community of penitent sinners is held together by the unity of the body of Christ" $(1930 / 1998,212)$.

${ }^{15}$ See Anderson (2002) for a more detailed discussion of the Catholic theology of the Church's sin. See also Jeremy Bergen's (2011) discussion of ecclesial repentance.

${ }^{16}$ Because of this emphasis on disunity as a result of human sin, Fee notes that we must be careful not to force our own human "brand of 'spiritual unity' on the church as simply another human machination. Our desperate need is for a sovereign work of the Spirit to do among us what all our 'programmed unity' cannot" $(1987,607)$.

${ }^{17}$ TF Torrance writes that, "the clauses on the Church do not constitute an independent set of beliefs, but follow from belief in the Holy Spirit, for holy Church is the fruit of the Holy Spirit.... If we believe in the Holy Spirit, we also believe in the existence of one Church in the one Spirit" $(1988,252)$.
} 


\section{Christ has authority and headship over the Church.}

While the Spirit is integral in the work of uniting the Church, the New Testament is keen to stress that Christ is the "head" (in the body metaphor) (Colossians 1:18) or the "cornerstone" (in the building metaphor) (Ephesians 2:19) of the Church. That is, the unity of the body is the will of Christ, actualised by the work of the Spirit. As Ernest Best maintains, the centrality of Christ for one's ecclesiology is key to understanding claims about the Church's unity. Best writes that the unity of the Church "is not ... imposed from outside; Christ is himself the unity.... The Church, as Body of Christ, is a unity, but a unity with Christ. It is not identical with him; but it is not separate from him" $(1955,96)$. While there is some theological controversy in how best to understand the relationship between the work of Christ and the Holy Spirit in bringing about this unity, ${ }^{18}$ the above claim seeks to outline something fairly minimal in relation to the Church; namely, that the unity of the Church is the work of the Spirit (however this work is understood) which actualises the will of Christ.

With these parameters in place, let us now consider the philosophical literature on the nature of social groups.

\section{Groups as agents: Mapping out the positions}

To begin, it will be helpful to map out the different positions one might hold concerning the ontology of groups. First, it is important to observe that regardless of one's group ontology, talk of groups is common place in everyday language. For instance, we talk of a government's believing in certain values, of the unethicality of a company's actions in the financial crisis, of the sublimity of a jazz quartet's performance, and of a class's good behaviour in a school lesson. In other words, we speak as if groups are capable of holding beliefs, performing actions, and being held responsible. But just because group-talk is part of our language, it does not necessarily follow that it must be part of our ontology.

Indeed, some group-talk clearly appears to be either metaphorical, or misconceived. For instance, Anthony Quinton writes,

We do, of course, speak freely of the mental properties and acts of a group in the way we do of individual people. Groups are said to have beliefs, emotions and attitudes, and to take decisions and make promises. But these ways of speaking are plainly metaphorical. To ascribe mental predicates to a group is always an indirect way of ascribing such predicates to its members.... To say that the industrial

\footnotetext{
18 Alastair McGrath discusses the relationship between the Spirit and Christ in the context of the Church, and notes that this issue is theologically contentious $(2011,387)$. In Ignatius's theology, for instance, the Spirit actualizes the presence of Christ in the community of the Church, whereas in thinkers such as Leonardo Boff, the work of the Spirit is to make us conscious of the saving work of Christ in forming the Church $(1986,11)$. In the Eastern Orthodox tradition, John Zizioulas (1985) describes the Spirit as constituting the Church which was instituted by Christ.
} 
working class is determined to resist anti-trade union laws is to say that all or most industrial workers are so minded $(1975,17)$.

While some might think it metaphorical or misconceived to think of the working class as existing above and beyond its individual members, endorsing eliminativism about groups, in the way Quinton describes here, misses something important about the social world. Group eliminativism does not allow us to criticize or make ethical constraints on groups unless we can reduce the behaviour to individual behaviour. Yet, group behaviour is not easily separable in this way. As Peter French argues,

"The Democratic party nominated George McGovern" is not reducible to a series of statements about the votes cast by each member of the party. Each delegate at the national convention casting a vote for McGovern was, we assume, behaving in a standard and acceptable fashion; that is, each voted for the candidate he favoured and that is precisely what delegates are expected to do. The fact that McGovern was nominated ... was the result of the way the Democratic Party was then organized $(1984,14-15)$.

French's point is simply this: to reduce group-talk to individual-talk is to miss something vital about the way in which these individuals are structured in relation to the group, without which, we cannot understand the actions described by group-talk. If group eliminativism is true, then we cannot hold corporations responsible for their actions, or place ethical demands on political parties, but we can only dictate what individual members of these groups can or should do.

While there is not space here for a detailed rejection of eliminativism about groups, in what follows, I assume that there is at least some group-talk that cannot be reduced to talk about individuals. Moreover, we need not go too far into thinking about the possibility of group eliminativism in relation to the Church, since to do so would be to do disservice to Scripture's emphasis on the reality of the Church, as well as the rich theological tradition affirming that we should take the existence of such a Church seriously. Putting aside the possibility of providing an eliminativist account of the Church, then, let us consider how we might think of the Church in group-realist terms.

Discussions of group realism have historically fallen into one of two camps, which, borrowing from Christian List and Philip Pettit, can be divided into "redundant" and "non-redundant" group realism $(2011,7)$. As I will explain shortly, there are further divisions to be made within these two camps but let us begin by considering these two historical positions. The diagram below (List and Pettit, 2011, 7) indicates how these positions divide: 


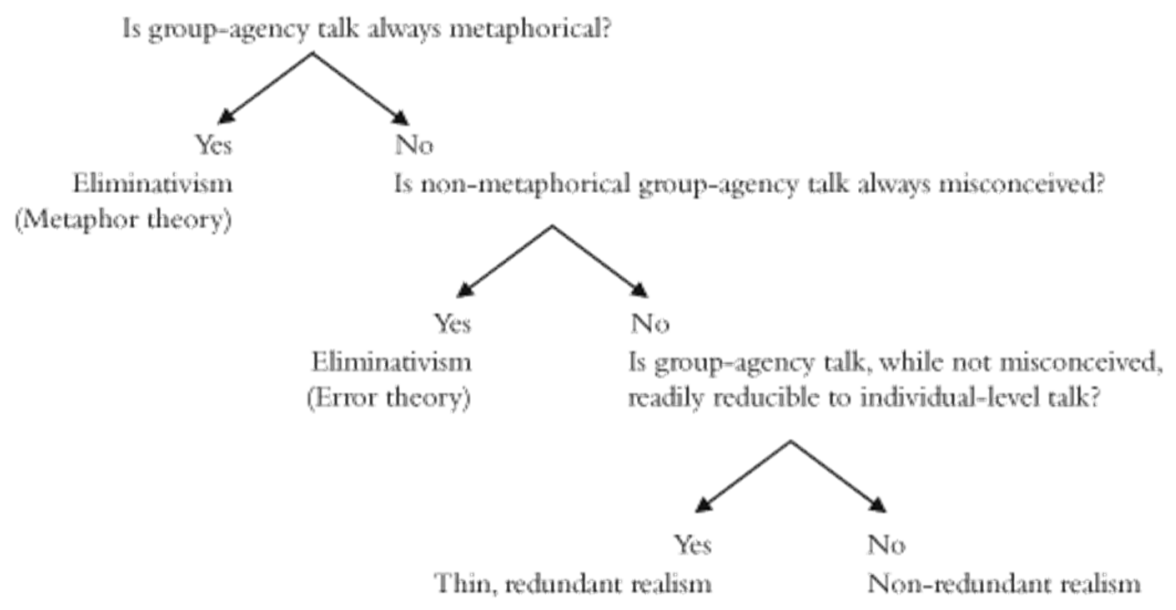

First, a kind of redundant realism has been defended, particularly in the context of political philosophy. Such accounts typically defend an authorization model of group agency in which what it is for the group to act can be explained entirely in reference to some individual who is authorized to act on behalf of the group. For instance, in the work of Thomas Hobbes (1651/2003), John Locke (1690/2004) and Jean-Jacques Rousseau (1762/2007), we find examples of models which fit this category. In Hobbes's Leviathan, he describes a kind of group-realism of a state in which the citizens authorize an individual (such as a monarch), or a small group (such as an aristocracy) to speak on behalf of the state. Hobbes writes that,

A Multitude of men, are made One Person, when they are by one man, or one Person, Represented; so that it be done with the consent of every one of that Multitude in particular. For it is the Unity of the Representer, not the Unity of the Represented, that maketh the Person One. And it is the Representer that beareth the Person, and but one Person: And Unity, cannot otherwise be understood in Multitude $(1651 / 2003,114)$.

On this account, group agency arises due to a group of individuals collectively authorizing some individual (or group of individuals) to act on their behalf. Such accounts can be described as redundant realist accounts since everything we can say of the group as an agent can be explained in relation to the individual who has been authorized to act on behalf of a group. In other words, while this model is realist about the ontology of groups, the explanation of how groups think, act, and deliberate is entirely explicable by giving an account of how the authorized individual thinks, acts, and deliberates. In the next section, I will consider the application of such a model to thinking about the Church as a unity. First, however, it will be helpful to consider how we might provide a non-redundant group realism.

Historically, most accounts of non-redundant group realism have been versions of a kind of animation theory. Such theories claim that group level agency emerges from a collection of individuals through some mysterious force or spirit. One of the most prominent of these accounts is Otto von Gierke's (1934) Natural Law and 
the Theory of Society. ${ }^{19}$ Just as our human bodies are composed by individual parts, which organically unite to form a whole entity which is more than the sum of its parts, we can think of corporate bodies as organically united bodies constituted by individuals. On such accounts, language of organic wholes or bodies is used as a kind of black box, in which a mysterious entity emerges from a collective of individuals. While similarly to authorization accounts, animation accounts are realist about groups, unlike authorization accounts, animation theorists think that co-ordination between individuals is insufficient for providing a group ontology. What is needed in addition is some mysterious force which unites groups together.

Furthermore, animation accounts of group agency are generally antiindividualist, thinking that individuals must be understood in relation to groups (rather than the other way around). For instance, F.H. Bradley writes that, "To know what a man is ... you must not take him in isolation... The mere individual is a delusion of theory" $(1876,173-174)$. Individualism, in this context, is the thesis that "economic and social explanations should resist any appeal to psychologically mysterious social forces" (List and Pettit, 2011, 3). Just as the physicalist claims that we should not appeal to any mysterious force or substance to explain the workings of the mind (even if she rejects eliminativism about minds), the individualist about groups holds that we should not appeal to any mysterious force or substance to explain the workings of groups (even if she is not an eliminativist about groups).

While historically, group-realism has tended towards either metaphysically mysterious accounts of groups, that depend on rejecting individualism, or accounts that are reducible to individual actions and beliefs, there have been some recent attempts to offer a third way of thinking about groups. The table below (amended from List and Pettit $(2011,10)$ ) is a helpful way of seeing what such an account might involve:

\begin{tabular}{|l|l|l|}
\hline Realist theories & $\begin{array}{l}\text { Redundant or non- } \\
\text { redundant } \\
\text { agency talk? }\end{array}$ group- & $\begin{array}{l}\text { Methodologically } \\
\text { individualistic or not? }\end{array}$ \\
\hline $\begin{array}{l}\text { Authorization theories } \\
\text { (e.g. Hobbes, Rousseau, } \\
\text { Locke) }\end{array}$ & Redundant & Individualistic \\
\hline $\begin{array}{l}\text { Animation theories (e.g. } \\
\text { von Gierke, Figgis, } \\
\text { Maitland) }\end{array}$ & Non-redundant & Non-individualistic \\
\hline $\begin{array}{l}\text { Functionalist theories } \\
\text { (e.g. List \& Pettit, } \\
\text { French) }\end{array}$ & Non-redundant & Individualistic \\
\hline
\end{tabular}

Recent work in analytic philosophy has attempted to give an account of group agency which combines features of these two historical accounts. Functionalist accounts seek to affirm the intuitive aspects of both accounts, while overcoming the difficulties

19 Other accounts include J.N. Figgis (1914) and F.W. Maitland (1911). See Runciman, 1997 for a summary of this literature. 
associated with both. Like the authorization approach, such accounts seek to give an individualistic, non-mysterious account of group agency. Yet, unlike the authorization approach, and like the animation theorists, they attempt to show how group-talk is non-redundant. Such accounts generally begin by stipulating conditions for a thing's counting as an agent, and then ask whether groups can meet these conditions. It is important to note that endorsing a functionalist account of group agency does not commit one to saying that groups have conscious states; as Deborah Tollefsen describes, "agency is best thought of on a spectrum, with very simple agents at one end and very complex agents at the other. Perhaps the very complex ones are conscious, and the simple ones are not. Agency isn't an on and off switch" $(2015,53)$. However, it does commit one to saying that groups are the kind of things which can hold propositional attitudes such as beliefs. Thus, Tollefsen concedes, "[i]f you are a person who thinks that propositional attitudes are states only of phenomenally conscious beings, then group mental states are going to be a particularly difficult thing for you to swallow" $(2015,53)$.

Let us consider functionalist accounts in more detail. French (1995) stipulates that agents must display the capacities for intentionality (i.e. they must do something for a reason or purpose), rationality (i.e. they must be responsive to arguments that concern these reasons), and they must be able to respond to criticism (i.e. they must be capable of adjusting their actions accordingly) $(1995,10-12)$. French argues that many corporate groups meet these criteria, and so should be considered agents. List and Pettit endorse a similar account of agency and develop this in more detail. They suggest that,

an "agent", on our account, is a system with these features: it has representational states, motivational states, and a capacity to act on their basis. When processed appropriately, the representational states co-vary with certain variations in the environment: for example, with the changing positions of cylinders. And the motivational states leave the agent at rest or trigger action, depending on whether the motivating specifications are realized or unrealized in the represented environment $(2011,20)$.

On this account, to be considered an agent something must have (1) representational states, (2) motivational states, and (3) a capacity to act on these states. Note that to be an agent on this account, is not sufficient for personhood. List and Pettit's first example of something which fulfils these criteria is a robot which "acts to maintain the pattern of upright cylinders in a recalcitrant and changing world, where cylinders topple under various influences" $(2011,20)$. As they expand these conditions, "A state is 'representational' if it plays the role of depicting the world, and 'motivational' if it plays the role of motivating action" $(2011,21)$. However, they note, their position does not specify the "precise physical nature of intentional states," but only "the appropriate functional role" $(2011,21)$. This functional role could be fulfilled by a human being, a goldfish, a robot, or even a group of individuals.

Given this account of agency, we can now consider how a group can be considered an agent in its own right. The majority of examples of group-agency 
require some level of cooperation or collective intentionality between individual group members. In many cases, a group of individuals "intend that they together act so as to form and enact a single system of belief and desire, at least within a clearly defined scope; they each intend to do their own part in a salient plan for ensuring group-agency within that scope, believing that others will do their part too" (2011, 34). The relationship between the individual and the group will partly depend on one's role in the group. For instance, one might take an active role in the group, in which one acts with "full awareness for the pursuit of the group's ends" $(2011,35)$. That is, they act wholly or partly on behalf of a group when they act. For instance, a negotiator in a trade union acts on behalf of all the members in the group for the interests of the group as a whole when negotiating a better financial deal with a government or organization. An individual can also take an authorizing role in the group. In such a case, she may not actively contribute to the actions of the group, but in virtue of her membership, she endorses and authorizes those who do act on behalf of the group. For instance, in being a member of a trade union, one authorizes a negotiator or management group to speak on behalf of the group.

It is important to note that on this account, the way in which the group meets the conditions for agency depends on the structure and decision-making processes of the group. As List and Pettit note, "to count as an agent, a group must exhibit at least a modicum of rationality. And so its members must find a form of organization that ensures, as far as possible, that the group satisfies attitude-to-fact, attitude-to-action, and attitude-to-attitude standards of rationality" $(2010,36)$. In the case of a corporation, for instance, these conditions for rationality will be met by those who are responsible for the group's actions, by means of an appropriate system of voting or group deliberation. ${ }^{20}$

In the next section, I consider to what extent these accounts of group agency can help us to understand the agency of the Church.

\section{The Church as a group agent: The application of social ontology to ecclesiology}

Let us return to our map of realist positions on group ontology and consider their potential for thinking about the Church as a group agent.

First, we might think, there are good reasons to endorse an authorization theory of the Church. Indeed, since we wish to say that the work of the Church is primarily the work of the Holy Spirit in conformity with the will of Christ, the authorization model looks promising. ${ }^{21}$ However, we can quickly dismiss such a

\footnotetext{
${ }^{20}$ I will not unpack the detailed account of group deliberation endorsed by List and Pettit, for as we will see, such deliberation clearly does not occur in the Church.

${ }^{21}$ Some strands of reformed theology appear to propose an account of ecclesiology which has notable similarities to authorization ontology. For example, as J.B. Torrance (1996) describes, in the Church, Christ provides both the "substance" of worship as well as acting as the "real agent in all true worship" (1996, 4-5). On Torrance's account of worship, Christ's actions provide not only the God-tohumanward actions of saving human beings, but also, the human-to-Godward actions of responding to
} 
possibility if we wish to claim that the itself Church is to be regarded as sinful (in the way Bonhoeffer describes, for instance). Moreover, if we wish to think of the Church as divided (as stipulated in 3) because of the sin of its members (as stipulated in 4), then it appears difficult to endorse the authorization account. It is important to note that there must be more than divine agency at work in the agency of the Church, even if the Spirit is the primary agent at work in the Church. On an authorization model, the actions of the Church are explicable only in reference to Christ or the Holy Spirit. If we assume God is incapable of sinning, then it is difficult to see how an authorization model could explain the sin of the Church.

Let us consider whether animation accounts have more potential to explain the Church's ontology. There are many intuitive reasons to endorse such a view, and many philosophers and theologians have given such an account. For instance, Neville Figgis, writing in Churches in the Modern State builds on an animation theory to explain the ontology of the Church. Figgis asks:

Does the Church exist by some inward living force, with powers of selfdevelopment like a person; or is she a mere aggregate, a fortuitous concourse of ecclesiological atoms, treated it may be as one for purposes of convenience, but with no real claim to a mind or will of her own? $(1913,40)$

Answering his own question, he continues,

It is, in a word, a real life and personality which those bodies are forced to claim, which we believe that they possess by the nature of the case, and not by the arbitrary grant of the sovereign. To deny this real life is

God in worship. Torrance writes that, Christ is "our great High Priest and ascended Lord, the one true worshipper who unites us to himself by the Spirit in an act of memory and in a life of communion, as he lifts us up by word and sacrament into the very triune life of God" $(1996,5)$. In other words, Torrance describes Christ as acting as mediator on behalf of all humanity in his worship of the Father. This model of the Church's worship looks remarkably similar to the Hobbesian picture of authorization action in government. Just as the people authorize a person or group to speak and act on their behalf, we might think that through our union with Christ and participation in Christ, we authorize Christ to act on our behalf in responding to the work of the Father. On Torrance's picture, worship is not something we engage in, but something we participate in through the ongoing work of Christ. And thus, we might suppose that a model of Church agency needs only to provide an account of the agency of Christ and an account of our union in Christ in order to give an ontology of the Church. Yet, even in Torrance's account, we contribute something to the worship of the Church, however minimal this may be. What Torrance wishes to resist is the kind of individualism which emphasises the importance of the individual's response in worship. And so, it is not clear that an authorization model entirely captures Torrance's description of worship.

However, as a referee helpfully points out, one strongly in the Reformed camp might argue that fallen humans clearly cannot offer laudable worship to God and so any contribution to worship can only be the work of the Holy Spirit, thereby claiming that the authorization model is correct. On this way of reading Torrance's account, it is not that we authorize Christ to act on our behalf, but that Christ authorizes us to engage in true worship (with thanks to Philip-Neri Reese for this suggestion). Unfortunately, there is not space to fully explore these connections here. 
to be false to the facts of social existence and is of the same nature as that denial of human personality which we call slavery $(1913,42)$.

The animation account takes seriously the organic metaphor presented in Scripture to explain the ontology of the Church and the relation between the Church and its members-organic metaphors are common place in explaining not only the ontology of the Church, but also of society more generally. Indeed, such a position provides an intuitive way of explaining the initial constraints outlined in the first section.

However, there are reasons to be dissatisfied with such an account. ${ }^{22}$ The animation account is not individualistic enough to provide a useful application to Christian theology. Richard Bauckham (2015), writing on the Gospel of John, notes that while biblical scholars are right to resist a certain kind of individualism in interpreting the New Testament, they should resist endorsing a position which affirms that the collective is somehow more real than the individual. He notes that while "Human beings in all cultures throughout history have been aware of themselves as distinct subjects of feeling, thinking, decision and action" $(2015,3)$, not all cultures have a "strong sense of unique personality that modern individualism entails" in which the individual is "the sovereign arbiter of his or her destiny in the modern 'I did it my way' sense" $(2015,3)$. Writing on the relationship between community and individual in the Gospel of John, Bauckham argues:

The life of the community, the disciples' mutual love, stems from the relationship between each individual and Jesus. The latter entails the former, but individual relationship to Jesus has priority. The community is constituted by individual relationship with Jesus and subsists only through individual relationship with Jesus. $(2015,9)$

For these reasons, I think we ought to resist any social ontology of the Church which thinks of the Church's existence and relationship to God as more real or more important than the individual's relationship to God. Many of the animation theories of early $20^{\text {th }}$ Century sociology do just this. Indeed, Bonhoeffer raises a very similar concern with the application of animation theories to explain the collective personhood of the Church. While Bonhoeffer thinks that animation theorists are right to stress that human beings are structurally open (i.e. the self is defined in relation to the other), we cannot make sense of this notion without also describing human beings as structurally closed. Bonhoeffer argues that,

\footnotetext{
${ }^{22}$ Another concern with animation accounts concerns the description of the Spirit only as a uniting force. This downplays the significance of the Spirit as a person. If we are to take seriously an Athanasian Trinitarian theology in which the Spirit is a co-equal divine person, then we should think of the Spirit as having a will and an agency in His own right. But as an anonymous referee points out, this objection is not decisive and many contemporary theologians writing on pneumatology describe the work of the Spirit as that of a mysterious force. Thus, while there may be Athanasian motivations for rejecting this view of the Spirit, the modern theologian who endorses the animation view might just bite the bullet here.
} 
the "openness" of the person demands "closedness" as a correlative, or one could not speak of openness at all. In a certain sense, therefore, the question whether individual being exists, untouched by all social bonds, must be answered in the affirmative, in order not to give up the idea of the I-You-relation.... The tragedy of all idealist philosophy was that it never ultimately broke through to personal spirit. $(2009,73-74)$

And thus, if we wish to take seriously Bauckham's concern in claiming that the Church is constituted by individual disciples of Christ (claim 1 of the initial constraints), then we should look to a social ontology which affirms the individual.

Thirdly, let us consider the applicability of functionalist accounts of group agency. In some respects, this model looks the least well suited for the context of ecclesiology. List and Pettit spend a considerable amount of time giving an account of the deliberative processes by which corporations and organisations can meet the conditions for agency. While some of this may be relevant to thinking about the work of gathered church communities, it looks like a poor fit for explaining the agency of the Church as a whole. ${ }^{23}$ For while committees and hierarchies undoubtedly play a role in the decision-making processes of individual churches and denominations, it would be strange to suggest that such processes have much to do with the Church's actions as a whole. If we are members of the Church as a functionalist group agent, then clearly none of us have a particularly active role to play in the Church's agency. This is a point Underhill makes, albeit in very different terms. She writes,

This total liturgical life of the Corpus Christi is not merely a collective of services, offices, and sacraments. Deeply considered, it is the sacrificial life of Christ Himself; the Word indwelling in His Church, gathering in His eternal priestly action the small Godward movements, sacrifices, and aspirations of 'all the broken and the meek,' and acting through those ordered signs and sacraments by means of these His members on earth. Whether this Church be given hard and fast juridical boundaries, as in Roman Catholicism, or is seen as a group of autonomous families, as by Anglicans and Orthodox, or felt to be independent of visible expression, as by Quakers and other Independents, the principle is the same: the eternal self-offering of Christ to God in and through his mystical body. Hence the corporate worship of the Church is not simply that of an assembly of individuals who believe the same things, and therefore unite in doing the same things. It is real in its own right; an action transcending and embracing all the separate souls taking part in it. The individual as such dies to his separate selfhood-even his spiritual selfhood-on entering the Divine Society: is 'buried in

\footnotetext{
${ }^{23}$ I think List and Pettit's account actually is relatively well suited to thinking about agency in the gathered Church, see (Cockayne, 2018) where I discuss this in detail. Indeed, List and Pettit even suggest that such an application may be appropriate in writing, "In a hierarchical organization, such as a commercial corporation or a church, there may be differences in the members' roles, for example through holding different offices or through belonging to subgroups with different tasks" $(2011,36)$.
} 
baptism' and reborn as a living cell of the Mystical Body of Christ (1936, 86).

The worship of the Church is not some summation of all of the deliberating processes of the gathered churches and individuals which constitute it. While the authorization model gives too little role for the actions of individuals in contributing to the agency of the Church, the functionalist model gives too great a role. Thus, List and Pettit's model of functional group agency looks difficult to extend in thinking about the Church.

The picture looks bleak, then, for applying social ontology to help think about ecclesiology. However, in the next section, I develop an alternative functionalist account of the Church's ontology, by building on some brief remarks which List and Pettit make at the beginning of their account. I suggest that some version of the functionalist account can meet the criteria laid out in the first part of this paper.

\section{Honey Bees and Terrorist Cells: A better functionalist ontology of the Church}

Underhill's claim that Christ acts "through those ordered signs and sacraments by means of these His members on earth" $(1936,86)$ can provide a helpful point for thinking about what participation in the Church consists in, in such a way that does not reduce to authorization, but which does not depend too heavily on human agency either.

List and Pettit's primary concern in Group Agency is to provide an account of how corporations and other groups could be considered agents, and therefore responsible agents, capable of being held to account for their actions. Yet, before outlining this account, they offer some brief provocative remarks about how a group can be considered an agent, without any joint intentionality from its members. First, List and Pettit suggest that, by "a process of natural or cultural evolution" members of a group might possess certain traits that "lead them to act as required for group agency" $(2011,32)$. While they admit there are no obvious human examples of such phenomena, they note that we can observe something like this in the natural world. For instance, consider the following description of the decision-making processes of honey-bee colonies:

It is a long-standing empirical fact that, in late spring or early summer, a colony of honey bees that has reached a certain size tends to divide itself: the queen leaves with roughly two thirds of the worker bees, and a daughter queen stays behind in the parental nest with the rest of the worker bees. How does the swarm that has left the colony find a new home? Empirical work... has revealed a mechanism involving a "search committee" of several hundred bees-the scouts-who fly out to inspect potential nest sites and then come back and perform waggle dances to advertise any good sites they have discovered. Initially, the 
scouts visit and inspect sites randomly, but once the dancing activity has built up, they are more likely to visit and inspect the sites advertised by others. Back at the swarm, each bee dances for the site she has inspected, with the duration of the dance depending on her perception of the site's quality: the better the site, the longer the dance. Thus high-quality sites receive more advertisement and are visited by more scout bees, which in turn generate even more dance activity for these sites. The process eventually leads to a "consensus": The dancing and visiting concentrates on one popular site, and the swarm moves there.... The striking empirical fact is that, when different possible nest sites vary in quality, the bees usually choose the best one (Seeley and Buhrman, 2001).

In this kind of case, List and Pettit suggest, "bees can combine, on the basis of simple signals, so as to perform as a group agent" $(2011,33) .{ }^{24}$ While no single bee has this complex level of decision making by itself, the swarm as a whole has "impressive powers of decision making, especially with respect to simultaneous-option decisions" $(2011,249)$. Thus, even though no joint intentionality (at least not in the way that this term is often used) is taking place in the bee colony, because of their natural interactivity, the bees display evidence of agency at a group level. List and Pettit write that, "It is harder to imagine, though not conceptually impossible, that nature or culture could work to a similar effect on human beings eliciting, coalescent agents" $(2011,33)$. Could such a possibility help to explain the agency of the Church? Perhaps so. I will return to this analogy shortly.

Before doing so, let us consider a second brief example of agency without joint intentionality. List and Pettit write,

A second way in which a group agent may form without joint intention is perhaps more plausible. This would involve one or several organizational designers co-opting others into a structure underpinning group agency, without making them aware of their agency at the group level and without seeking their intentional acquiescence in the arrangement. Think of the cellular organization by which, so we are told, many terrorist organizations have operated. We can imagine that a cellular network may be established for the promotion of some goals, without those recruited to the different cellular tasks being aware of the overall purpose; they may be kept in the dark or even deceived about it. The organization would be composed of a group of people, in perhaps a thin sense of group, and would function as an agent. But it would do so without joint intention among its members, with the possible exception of a few coordinators. $(2011,33)$

\footnotetext{
${ }^{24}$ To consider this example in more detail, see Seeley, 2001 and List, Elsholtz, and Seeley, 2009.
} 
Note that unlike the case of the honey-bee colony, in the case of the terrorist cell, there may be some basic level of joint intentionality between agents at a group level. Yet, it is the decision-making processes of those in positions of power that allows the group as a whole to function as an agent. The coordinators of the group's action would provide instructions, and guidance to those on the ground level, but those who participate at the ground level would act with no awareness of just how their actions contributed to the actions of the group as a whole. It is only through the contribution of all of the members that the necessary intentional states arise-both the coordinators and the enactors are necessary for allowing the group as a whole to act with the relevant motivational and representational states.

The above models have great potential to explain the agency of the Church as a whole, I think. While comparing the ontology of the Church to a terrorist organization might feel unsavoury to some, it provides some helpful insight in a number of areas. In what follows, I will describe my preferred model for the ontology of the Church-the modified functionalist model (MFM). On the MFM, the Church is a unified group which functions as an agent with representational and motivational states and is capable of acting on these states. It is constituted by individual Christian disciples and is united by the internal promptings of the Holy Spirit (akin to the individual bee's biological responses to one another) and the external commands of the Holy Spirit (akin to a terrorist overlord's commands to the cell). In filling this account out I will show where MFM fits alongside the other three models outlined in the previous section.

First, in contrast to the authorization model, MFM explains how human beings can contribute to, and participate in, the worship of the Church, while still allowing the primary agents to be Christ and the Holy Spirit. Like ground level terrorist cells and cell members, individual Christians act in submission to the group coordinators, namely, the Holy Spirit and Christ. Thus, in participating in the actions of the Church, members do not always act in full awareness of how their actions contribute to the actions of the Church as a whole. Thus, like Underhill stresses, Christ acts by means of the actions of the Church's members. In participating in the Church's worship, we are like obedient members of ground-level terrorist cells, who respond to the call of the group coordinators. It is the job of the coordinators to unite the actions of the members into a coherent group action, and to shape and instruct those on the ground level. On MFM, it is the role of the Holy Spirit to provide such unity. The Spirit takes our actions, performed in participation of some gathered church, or in private worship, and unites them in line with the will of Christ, the head of the Church. Thus, we can affirm that Christ is the primary agent in the Church's worship, while still affirming that our contribution in participating in this worship requires more than authorizing Christ to act on our behalf.

How does the Spirit communicate the will of Christ to the Church? By means of the revelation of truth in Scripture and by guiding individuals supernaturally in the practices of the Church. Underhill emphasises the importance of the Spirit's leading the outward forms of the Church's actions in worship, in writing,

We do not get a real view of the situation, unless we add to them (the Eucharist and Daily Office) another and very different form of 
expression; the free, enthusiastic, unstylized group worship, the spontaneous response to the stirrings of the Spirit, which began in the childhood of the Church and-now for the most part separated from her liturgical action-has continued in various expressions ever since, sometimes going underground for long periods but sooner or later breaking out with disconcerting vigour and freedom $(1936,87)$.

Here the analogy with honey bees becomes helpful. In faithfully responding to the will of the Spirit in worship, it might be possible for us to move from merely following the instructions of the Spirit, to instinctively coordinate with other Spirit-filled Christians. Unlike the terrorist cell, however, this may not require any immediate awareness of the work of the Spirit, but, rather, in responding obediently to God, we might, like honey bees, unite in ways more profoundly than we are capable of reflecting upon.

Thus, the work of the Spirit is twofold: (i) the Spirit takes a guiding role by revealing the will of Christ through prayer, Scripture, and by relating to the other members of the Church (i.e. in a similar way to the communication of terrorist coordinators), and, (ii) the Spirit takes a shaping role, by means of the Spirit's indwelling the individual believer, the Spirit shapes the actions of individuals in ways they may be unaware of, to conform to the will of Christ (i.e. in a similar way to the biological impulses of honey bees).

Secondly, also in contrast to the authorization model, this model allows us to describe the Church as sinful and can explain how human individuals, and not the persons of the Trinity, are the agents of sin. Here, the importance of the Holy Spirit in communicating the will of Christ becomes important. For just as members of terrorist cells can respond faithfully or unfaithfully to the instructions of their coordinators, we can respond faithfully or unfaithfully to the instructions of the Holy Spirit. The presence of rogue agents attests to this possibility within terrorist organizations. While rogue agents might occasionally act accidentally in line with the will of their coordinators in acting in defiance of their immediate instructions, often they do not. Rogue agents act from a sense of feeling more important than they actually are, and as considering themselves more informed about the will of the organization than they actually are. What could be a better picture of the defiance of individuals within the Church? Instead of submitting to the will of the Spirit, who unites our actions in ways unfathomable to us, all too often we assume that we have grasped the will of Christ sufficiently to act in our own strength. While these rogue actions might still be regarded as broadly under the umbrella of the Church as a group agent, they are contrary to the will of Christ, manifested by the instruction of the Spirit. And thus, since it is plainly the case that the Church often diverges from the will of the Christ, despite his desire for unity, we can regard the Church as sinful, as well as united.

Next, unlike the animation model, the MFM is individualistic about the human person. That is, we need not appeal to any mysterious force to explain the unity of the whole. Indeed, unlike the animation model, this unity is provided by means of the will of a person, or of a group of persons; the Holy Spirit manifests the will of Christ to the Church to bring about unity in action. While this model emphasises the importance of mystery in what Christ's specific will for the Church is, it does not appeal to some metaphysically strange force which emerges each time groups are formed. If the 
persons of the Trinity are to be considered persons, then I think we have no need to appeal to anti-individualism to explain the unity of the Church, we need only appeal to the coordinating will of the Trinity as the driving force of the Church's unity.

Finally, contrary to List and Pettit's functionalist model, MFM does not overstate the importance of the actions of individual participants. Individual participants contribute to the actions of the Church only insofar as Christ wills it to be the case, and only insofar as the gathered churches and individuals submit to the will of the Spirit in their participation in the Church. Thus, the MFM allows us to have a stronger notion of participation than the authorization model, but a weaker notion of participation than the functionalist model.

\section{Conclusion}

MFM meets all of the criteria laid out in 1-6. According to MFM, the Church is constituted by individual Christian disciples, who in turn, coalesce into gathered collectives (conditions 1,2). The unity of the Church is brought about by the work of the Spirit, who through instruction and guidance made possible by the liturgies of the Church, and his indwelling the mind of each individual believer, shapes the actions of the individual constituent parts to form motivational and representational states, which meet the necessary conditions for agency (condition 5). The Spirit enacts this work in line with the will of Christ, the head of the Church (condition 6). Finally, since each constituent member of the Church can reject or act in defiance of the will of Christ made manifest by the Holy Spirit, the actions of gathered collectives and individual disciples can diverge from the purposes of God, thereby bringing about apparent disunity within a united whole (conditions 3,4 ).

It is important to note that my claim in this paper is not that a modified functionalist social ontology can exhaustively explain the nature of the Church. Yet, in reflecting on the ways in which social ontology explains the nature of social wholes more generally, we have seen that there is much that can help explain the nature and ontology of the Church. In exploring these ideas, I hope that more philosophers and theologians in the analytic tradition will take seriously the need for thinking analytically about the Church. In particular, one of the topics which my proposed model depends heavily on, is the role of the Holy Spirit in uniting the actions of those who participate in the Church. Yet, just as the topic of ecclesiology has been largely ignored by analytic thinkers, the topic of pneumatology has received equally, if not lesser, attention. Perhaps, this article will provide the beginning of a conversation and that those working in analytic theology can see the importance and value of analytic ecclesiology. 25

\footnotetext{
25 This article would not have been possible without the invaluable feedback and advice of Koert Verhagen, over a number of conversations. I would also like to thank Jonathan Rutledge, David Efird, and an anonymous referee for their insightful comments on earlier drafts of this paper. Finally, many thanks to the Templeton Religion Trust for their generous funding during the writing of this paper.
} 


\section{Bibliography}

Abraham, William J. 2010. “'Church'.” In The Cambridge Companion to Christian Philosophical Theology, edited by Charles Taliaferro and Chad V. Meister. Cambridge University Press.

Anderson, C Colt. 2002. "Bonaventure and the Sin of the Church." Theological Studies 63: 667-689.

Antognazza, Maria Rosa. 2013. “Ecclesiology, Ecumenism, and Toleration." In The Oxford Handbook of Leibniz, edited by Maria Rosa Antognazza, Oxford University Press.

Arcadi, J.M. 2018. An incarnational model of the Eucharist. Cambridge University Press.

Avis, Paul (ed.) 2018. The Oxford Handbook of Ecclesiology. Oxford University Press.

Barrett, C.K. 1973. Second epistle to the Corinthians. A\&C Black.

Barth, Karl. 1959. Dogmatics in Outline. Harper \& Row.

Bauckham, Richard. 2015. Gospel of Glory. Baker Academic.

Bergen, Jeremy. 2011. Ecclesial repentance: the churches confront their sinful pasts. Bloomsbury Publishing.

Best, Ernest. 1955. One Body in Christ: A Study in the Relationship of the Church to Christ in the Epistles of the Apostle Paul. SPCK

Boff, Leonardo. 1986. Ecclesiogenesis: The Base Communities Reinvent the Church. translated by Robert R. Barr. Marynoll, NY: Orbis Books.

Baxter, Donald L.M. an Cotnoir, A.J. (eds.). 2014. Composition as Identity. Oxford University Press.

Cockayne, J., 2018. Inclusive worship and group liturgical action. Res Philosophica 95 (3): 449-476.

Crisp, Oliver D., 2017. “Analytic Theology as Systematic Theology.” Open Theology 3 (1): 156-166.

Cuneo, Terence. 2016. Ritualized Faith. Oxford University Press.

Dulles, Avery. 1978. Models of the Church. Doubleday \& Company Inc. 
Fee, Gordon D. 1987. The First Epistle to the Corinthians. Wm. B. Eerdmans Publishing.

Figgis, John Neville. 1914. Churches in the Modern State. Longmans Green and Co.

French, Peter. 1995. Corporate Ethics. Harcourt Brace.

French, Peter. 1984. Collective and Corporate Responsibility. Columbia University Press.

Gierke, Otto von. 1934. Natural Law and the Theory of Society 1500 to 1800. Translated with an introduction by Ernest Barker. Volumes $1 \& 2$. Cambridge University Press.

Hobbes, Thomas. 2003. Leviathian. Edited by Richard Tuck. Cambridge University Press.

Kirmmse, B.H. 2000. "The Thunderstorm: Kierkegaard's Ecclesiology." Faith and Philosophy, 17 (1): 87-102.

Küng, Hans. 1986. The Church. Ninth Edition. Translated by Ray and Rosaleen Ockenden. Search press.

List, Christian and Pettit, Phillip. 2011. Group Agency. Oxford University Press.

List, Christian; Elsholtz, Christian; and Seeley, Thomas D. 2009. "Independence and Interdependence in Collective Decision Making: An Agent-based Model of Nest-site Choice by Honey Bee Swarms." Philosophical Transactions of the Royal Society B 364: 755-63.

Locke, John. 1967. Two Tracts on Government. Cambridge University Press.

McGrath, Alister E. 2011. Christian Theology: An Introduction, Fifth Edition. WileyBlackwell.

Minear, P.S., 1960. Images of the Church in the New Testament. Westminster John Knox Press.

Nozick, R., 1981. Philosophical Explanations. Harvard University Press.

Quinn, P.L. 2000. "Kantian Philosophical Ecclesiology." Faith and Philosophy, 17 (4): 512-534.

Rea, Michael C. 2009. "Introduction." In Analytic Theology: New Essays in the Philosophy of Theology, edited by Oliver D. Crisp and Michael C. Rea. Oxford University Press. 
Rousseau, Jean-Jacques. 2007. The Social Contract and other later political writings. Eight Edition, edited by Victor Gourevitch. Cambridge University Press.

Runciman, David. 1997. Pluralism and the Personality of the State. Cambridge University Press.

Seeley. Thomas 2001. "Decision Making in Superorganisms: How Collective Wisdom Arises from the Poorly Informed Masses." In Bound Rationality: The Adaptive Toolbook, edited by Gerd Gigerenzer and Reinhard Selten. MIT Press.

Seeley, T.D. and Buhrman, S.C. 2001. "Nest-site selection in honey bees: how well do swarms implement the" best-of-N" decision rule?" Behavioral Ecology and Sociobiology 49 (5): 416-427.

Second Vatican Council. 1975. Vatican II: Conciliar and Postconciliar Documents, edited by Austin Flannery, OP. Costello.

Tollefsen, Deborah Perron. 2015. Groups as Agents. Polity Press.

Torrance, James B. 1996. Worship, Community and the Triune God of Grace. Paternoster Press.

Torrance, Thomas F. 2016. The Trinitarian Faith: The Evangelical theology of the ancient Catholic church. Second edition. T\&T Clark.

Underhill, Evelyn. 1936. Worship. Mayflower Press.

Wolterstorff, Nicholas. 2015. The God We Worship, Wm B. Eerdmans. . 2018. Acting Liturgically, Oxford University Press.

Wright, NT. 1997. The New Testament and the People of God, fourth edition, SPCK.

Zizioulas, John D. 1985. Being as Communion: Studies in Personhood and the Church. RSM Press. 